\title{
A Comparison of the Views of Ibn Khaldun and Montesquieu in Terms of the Effect of Climatic Conditions on Human Life
}

\author{
Aytekin Demircioglu \\ Faculty of Divinity, Sinop University, Turkey \\ E-mail: <demircioglu.aytekin@gmail.com>
}

KEYWORDS Natural Conditions. Temperature Climatic Zone. The Spirit of the Laws. Hot and Cold Weather

\begin{abstract}
There is a significant similarity between Ibn Khaldun, having lived in the Northern Africa in the fourteenth century and Montesquieu in terms of their ideas concerning the direct effect of geographical conditions and climate on human life. According to Ibn Khaldun, who divided the world into seven climatic regions from the south to the north, the fourth climatic zone located just in the centre is the most suitable place to live. The moralities and personality features of the people living in these regions are more moderate compared to other regions. Similarly, Montesquieu indicated that climate has an effect on the personalities, behavioural forms of people and the laws they enact. According to him, those living in the cold climatic zones are coldblooded, proud and keen on their security and freedom. As for the ones living temperate zones, it changes. In this study, the ideas of the two thinkers suggesting that natural conditions have an effect on people and communities were compared.
\end{abstract}

\section{INTRODUCTION}

The views that climate, land forms, natural conditions, geographical features have a direct and significant effect on human being and social life have been expressed from the early ages onwards. According to this view, a great many things dealing with human life such human characteristic, behaviouristic forms, social relations social institutions and legal rules have a close relation with the natural environment, climatic and geographical features where human being exists.

It is likely to make a connection between the views of Aristotle and Montesquieu in terms of the effect of nature on human life and the laws of communities (Long 1996). Similarly, a parallelism could be made between the views of Aristotle saying that people living in cold climates are keen of their freedom and those living hot climate ignore it and those of Ibn Khaldun claiming that the Bedouins living in hard natural conditions are brave people who are fond of their freedom.

Despite the difference of three-hundred years of time between them, Ibn Khaldun and Montesquieu had a common point in terms of the fact that they pointed out climate and geographical

Address for correspondence:

Dr. Aytekin Demircioglu,

Assistant Professor,

Department of Phiolophy and Religious Sciences,

Sinop University, Sinop, 57000, Turkey

Telephone: +903682715518,

E-mail: demircioglu.aytekin@gmail.com conditions have an impact on human life. Due to the parallelism in their subjects, JV Hammer could not help saying "Montesquieu of the Arabs" for Ibn Khaldun when he first read Muqaddimah (Introduction). Also, Russian scientist A. Krimsky said "Montesquieu of Islam" for Ibn Khaldun (Uludag 2009, 120). There is a chronological mistake in these descriptions. Ibn Khaldun got to know the West quite late and are less popular compared to Montesquieu. Therefore, those reading Ibn Kkhaldun for the first time likened him to Montesquieu. However, when a connection is to be made between them, the timely difference with regard to the period they lived should be taken into consideration and Montesquieu should be likened to Ibn Khaldun, just like opposite. In other words, instead saying "Montesquieu of the Arabs" or "Montesquieu of Islam" it would be true to say "Ibn Khaldun of the French" or "Ibn Khaldun of Christianity” for Montesquieu.

\section{THE VIEWS OF IBN KHALDUN IN CONTEXT WITH THE EFFECT OF NATURAL CONDITIONS ON HUMANLIFE}

Ibn Khaldun starts to explain the theory of climate saying that the world is a globe and in the very early ages, the globe was surrounded by water, however with the descent of the water later on lands appeared and became suitable for human to live on. According to him, geographers divided the globe into two with an imaginary 
line (equator line). After this division, there became more lands in the north and more seas in the south. Therefore, since the north of the world was more available for living, it had the majority of the world's population. According to him, this part of the world, which makes living available were divided into seven climatic regions from the south to the north. The places which have the best conditions to live are the fourth place which is in the central part of these seven regions. In other climatic regions, the conditions which facilitate life decrease as you stay further than the central part. For that reason, the fifth layer next to the forth climatic part from the north and the third layer next to the forth part are the second most available regions for living (Ibn Khaldun 2012, 1/II-III). According to Ibn Khaldun, the thing that facilitates life in the central parts and makes life difficult in the other parts is the weather temperature. Central parts have a warm weather and hotness and coldness are higher in other parts. Thus, it is difficult to live in the places without a warm weather to establish a civilization, to make these places prosper. That's why, according to Ibn Khaldun, one of the prerequisites of establishing a civilization in a region is related to how much the climate there allows human for a life.

In the fourth climate zone and the third and fifth zones next to it, everything including sciences, arts, buildings, clothes, foods, fruit, animals and all living things are in their best position due to suitable weather conditions. Best people in terms of sizes, colours, morality and religion live in this zone. In fact, prophecy emerged in these places, since there is no information about the prophecy in the northern and southern parts except for these three climatic zones. (Ibn Khaldun 2012, 1/III). Ibn Khaldun supported his claim with the explanation that prophets should be perfect in their body sizes and mentality, so these kind of people could only emerge from the central zones. And according to him, people do not want to believe in what a person having no good appearance both physically and mentally says.

For that reason, prophets must be perfect people in these issues (1/III, 123). It is not possible to get concrete evidence to support or refute Ibn Khaldun's claim that no prophets were sent to the climatic zones except for the central ones. Actually, the third, fourth and fifth climatic zones for which Ibn Khaldun said the perfect zones have the majority of the world's population. Therefore, it seems reasonable that a great majority of the prophets were sent to these regions. However, even though it is told in Qur'an that there were twenty-four thousand prophets, only twenty-eight prophets were mentioned and it shows that what is known about in this issue is very limited compared to the unknown. In addition, the ayah (verse) “... nor would We visit with Our Wrath until We had sent an messenger (to give warning) (Qur'an 17: 15) and another ayah “... and there never was a people, without a warner having lived among them (in the past) (Qur'an 35: 24) make what Ibn Khaldun said a bit troublesome, since according to these ayahs prophets and messengers were sent to all human communities. Thus, these approaches of Ibn Khaldun are not in a good accord with the religious knowledge.

According to Ibn Khaldun, communities living in the fourth climatic zone are perfect in all respects. The houses, clothing, foods and professions of these people are developed. They are good at mining iron, copper and zinc and tin. They use two precious metals, gold and silver, as cash money in their commercial and economic issues. These people who are far from extremism live in Maghrip, Syria, Hedjaz, Yemen, Iraq, India, Indus and China. Due to their vicinity to these regions, Andalusia, some southern parts of Europe and people living in Greece and Anatolia can be included in this group. According to Ibn Khaldun, the best places to live among these regions are Iraq and Syria (Ibn Khaldun 2012, 1/ III). In the current time, these regions are in the geography of Middle East where political conflicts and turmoil are experienced. This case could be regarded as follows: the reason for such a big turmoil in these regions result from the wish of people to conquer such valuable places and try to have superiority in the region. In other words, these regions are of great importance in terms of various political and geopolitical reasons. That is to say, the importance of the regions for which Ibn Khaldun put an importance six hundred years ago in terms of their climates increased in the current time; since some valuable elements which made these regions valuable were added to the climate.

While evaluating the people living in the first and second climatic zones near to equatorial line and those living in the sixth and seventh climatic zones around poles, Ibn Khaldun pointed out 
that these people are far from normality in all respects. He expressed in his examples that these people build their houses using muds and reeds, they provide their food from corn and plants, they produced their clothes out of the leaves of trees and animal skins, and some even do not know how to clothe and wander around naked. According to him, the products grown here are mostly wild products that are not suitable for consumption. Gold and silver coins are not used for purchase in these regions. Instead of these coins, metals in less value are used. Ibn Khaldun expressed that a great many Sudanese people who is considered to be the ones living in the first climatic zone live in caves and forests just like wild creatures and that heard about their eating animal flesh. Indicating that people living in the seventh climatic zone such as Eskimos and some Slave tribes are mostly the same, Ibn Khaldun expressed that these people are animal which cannot speak rather than human being. The cases of these people are the same in religious aspect. They live unaware of prophecy and religion. However, according to Ibn Khaldun, all these negative features decrease as you proceed toward the central climatic zones (Ibn Khaldun 2012: 1/III). According to him some genealogists who are not fully equipped with the nature of beings maintain that some tribes such as Sudan descending from Ham, the son of Prophet Noah, are black because Prophet Noah cursed his son Ham and he blackened so. According to him, it is an explanation of those who are unaware of the effect of coldness and hotness on human being, since it is the climatic features that determines the colour of skin (1/III, 124). These claims of Ibn Khaldun that were made depending on his observations and sciences seem reasonable and sound.

Ibn Khaldun expressed some positive features while making such kind of negative comparisons between the people living in the first, second, sixth and seventh climatic zones and those living in the fourth, third and fifth climatic zones. However, it should be indicated that these two groups of climatic zones are not opposite to each other. According to him, as one proceeds far from the north and south in the fourth climatic zone which has the best climatic conditions, positive features decreases gradually. Otherwise, this evaluation does not bear a dilemma as a contrast of good climatic zones (four-three-five) and bad climatic zones (one-two-six)
According to Ibn Khaldun, the tempers of those living in the central climatic zones are good just like their bodies, since their status such as income, habitat, profession, science, presidency and royal authority are developed. Therefore such institutions as politics and prophecy, some higher situations like property, states, laws, sciences, cities and towns, architectural and other professions have always existed in these zones. Just like the claims that black people were turned into black with a curse, some scientists in these communities claimed that the communities living there are developed due to a feature coming from their races. According to Ibn Khaldun, even though the effect of heredity is accepted to some extent, the essential effect on the development communities are the positive living conditions provided by climate and also the positive effect of climate on their personality (Ibn Khaldun 2012, 1/III). In the states which Ibn Khaldun maintained in the central climate zones, these institutions and their features were improved. Reaching the results with his observations, Ibn Khaldun wanted to base the situations he observed on climate and tried to make a connection between the climate and social development through a determinist link.

Ibn Khaldun thinks that there is a link between the hotness of the climate and moral structure of people. According to him, hot weather becomes vaporized and condenses, so leading to better penetration into the grains. Therefore, people living in hot climate are wanton, hasty, and keen on their pleasure, curious of music and dance and foolish people. Depending on his own observations and also the expressions of others, he says that Sudanese (black) people have all these features. The nature of fun and joy is made up of the expansion of animalistic spirit. Hot weather is the basic component extending this spirit. The nature of sorrow and sadness is just opposite; that is to say, it is the case of timidity and retention of this animalistic spirit. The reason why drunkenness adds an excessive joy to human is the situation of expansion in the spirit. Due to this expansion, the effect of alcohol penetrates into heart and person has an in vain joy and fun. Ibn Khaldun explains the joy situation at baths with this theory. According to him, people living by on the sea shore have a feeling of a relief and looseness if not for the Sudanese. It is likely to see the effect of looseness of the sea even in Algeria and Egypt which 
are located in the third climatic zone. These people are generally easy going and they never store their need for one month, let alone for one year. In the opposite, in Morocco, which is a bit colder, people have a hesitation and an intensive concern for the future. For that reason they store their food for two years (Ibn Khaldun 2012, 1/ IV). Ibn Khaldun pointed out that historian Mesudi mentioned about the fact that the Sudanese (black people) are wanton, indecisive and keen on their pleasures, but that he repeated the views of Galenos and Yakub bin Ishak Kindi instead of giving the reasons of this case. Galenos and Kindi wanted to explain it with a claim that the brains of the Sudanese are not so developed and therefore their brains remained weak. This explanation is far from a basis without any evidence for Ibn Khaldun (1/IV, $127-128)$. It is likely to say that the attitude taken by Ibn Khaldun is more reasonable compared to Galenos and Kindi in this issue.

Ibn Khaldun made a connection between the fertility of the land and the abundance of foods, and the various cases of people. Therefore, despite located in warm climates, not the land of every country has abundance in fertility. People living in these places are mostly in shortage; however, this case has a positive effect on their other status. As an example, the colours of these people are purer, their bodies are cleaner, their body shapes are proper, their morality is higher and their capacity of understanding is better. Ibn Khaldun explains it as such: overeating creates unnecessary wastes in the body and these wastes harm people, both physically, mentally and spiritually (Ibn Khaldun 2012, 1/IV). It is impossible to disagree what Ibn Khaldun reiterates, since modern experience and positive sciences confirms what he says in this issue.

\section{THE VIEWS OF MONTESQUIEU IN THE CONTEXT OF THE EFFECT OF NATURALCONDITIONS ON HUMAN LIFE}

Montesquieu, with his full name of Louis de Secondat, was born in a chateau in the town of la Bréde around Bordeaux in January 18, 1689. Having a law education, Montesquieu took over the duty of chief judge in 1716 . With a stronger tie with law, Montesquieu had a chance to tour a lot of countries in Europe between the years 1728 and 1731, making observations about the legal systems and ways of life in these countries. Hav- ing a great many works, the most prominent masterpieces of Montesquieu are "Les Lettres Persanes" (Letters of a Persian) published in Holland in 1721 (Montesquieu 2008); "Les Considérations sur les causes de la grandeur des Romains et de leur décadences" (Considerations on the Decline of the Romans) written in 1734 and published in Holland; The Spirit of the Laws" which is the most famous work of him and was published in 1748 (Macfarlane 2013, 5 - 7).

According to Montesquieu, laws are the necessary report deriving from the nature of events in its broadest meaning. Therefore, there are laws on which Gods, heavenly creatures, materialistic universe, humans, animals and all other beings depend. To him, there is a primitive cause in the universe. Laws are the connections between this primitive cause and beings. Without such a cause, it is nonsense to talk about the existence of the universe for him. From this point of view, God has also a connection with the universe as he is the creator and maintainer of it. The laws God depends on to create the universe are the same with those he depends in order to maintain the universe (Montesquieu 2014, 1/I).

From Montesquieu's perspective, something that exists was potentially existent before their existence. Therefore, their potential existence is the indicator of the fact that laws were also potentially existent before they exist. The constantly violation of the laws which human being readily found in the nature and sent to him by God is another evidence of this case (Montesquieu 2014, 1/I).

Montesquieu carried on the idea that laws and their causes are readily existent in the nature throughout "the Spirit of Laws". It is likely to say that the trips he made to Europe had an impact on creating such an idea. He observed the people, communities and the comparative events in the countries he visited in detail. He discovered in his observations that these necessary reports he caught in social relations and events cannot be arbitrary, in other words, they must be based upon a law or a principle. Finally, depending on the laws, he tried to make some objective explanations over the events. So, Montesquieu developed a method in order to make some social explanations over events moving to having a law in the nature then to factual explanations depending on the idea of factual determinism.

With these ideas, Montesquieu formed his own natural law. According to him, the source 
of law is in the nature and there cannot be a universal sense of law which is always valid everywhere, since human being himself who is both the creator and the implementer is changeable in nature (Gurkan 1988). There are a great many elements having an effect on human being and changing him such as climate, religion, laws, administrative politics, lessons taken from the past, morality and traditions (Montesqueiu 2014, 19/ V). What's more, there nothing a common standard in these elements. Some of them might have more effect on human being depending on space, time and conditions than others.

Putting an emphasis on the effect of climate upon human being in detail, Montesquieu started the fourteenth book of Spirit of Laws with these words: "If it be true that the temper of the mind and the passions of the heart are extremely different in different climates, the laws ought to be in relation both to the variety of those passions and to the variety of those tempers" (Montesquieu 2001: 14/I, 246). Montesquieu's introduction to the book with an expression of "if it is true" might be due to his intention to include the reader into the issue and attract the attention of the reader, since he would try to explain that there is an intense casualty between the structure of the climate and the human behaviours in a very decisive way in many parts following this expression.

Montesquieu had an effort to make a scientific basis for the theory of climate. Therefore, he maintained that the length and flexibility of the muscles in human body varies depending on the cold or hot weather and this is the essential factor having an effect on human behaviours. In this sense, those living in cold climates are brave and strong as their fibres or muscles in their body are short and flexible; since their hearts work better, the ends of the fibres give a good response and body fluids are more balanced. Due these superiorities in their body, they have a good selfconfidence, they are bold and they do not live with the sense of revenge, they do not need to cheat people and behave them hypocritically. As for the people living in hot climates have an opposite characteristic, since hot weather distorts the working conditions of fibres and heart cannot function fully and properly. Montesquieu tried to support his claim saying "Put a lot of man into a close, warm place, they will have tightness in their chest, they will feel a great faintness and cannot function well” (Montesquieu 2001: 14/II, 246-247).
However, Montesquieu carried on his expressions on this scientific basis which he believed sound. According to him, people living in the northern regions having strong fibres due to cold weather can digest foods easily. Such a case results in the fact that they have huge body shape but they are slow in their actions. Also, people living in the cold regions have tight skins with flattened breasts and their nerve ends do not work properly. Therefore, they can only feel strong senses. When it comes to those living in warm countries have a loose skin tissue with sensitive nerve ends. That's why, these people can feel any kind of sense very easily (Montesquieu 2014, 14/II). As a result, while people living in cold climates cannot be influenced by external factor so much, those living in hot climates are vulnerable to external effects.

People living in warm climates have a moderate character in terms of the feeling the pleasures. While people living in hot climates are fond of their pleasures, people living in cold climates are not so keen on their pleasures. In terms of feeling the pain and enduring it, people living in cold weather are more durable. As for love, people living in northern regions mostly deal with the physical pleasure of love, but people feel love in the dimension of emotion mostly towards the south and they become lovers as love adds happiness in life (Montesquieu 2014, 14/II).

As an expansion of feeling love in a different way in different climatic conditions, it is true that people have different characters in terms of morality. People in northern countries are not fascinated by the magic of love and their heart is not shaken so much, so they have less faults, have more good manners and they are sincere and open hearted. For that reason, it is likely to say that people living in cold climates are high in character in terms of morality. As it is descended towards the south, people chase their ambitions so much and they make more mistakes to realize them, also committing more crimes. Therefore, their level of morality is lower. As for people living in warm climates, they are indecisive in their behaviours whether they are good or bad. The climatic conditions in these regions are not so strong as eliminating this indecisiveness (Montesquieu 2014, 14/II).

According to Montesquieu, people living in Eastern countries have stayed weak spiritually with the effect of climate. For that reason, they cannot resist against the external effects and lived 
in the conditions where the rules were determined by others. Under such an effect, the laws, traditions, behaviours and condition adopted in these countries have their roots so deep that nobody has an attempt to change them (Montesquieu 2014, 14/IV). Montesquieu exemplify this case with India. According to him, nature did not give Indians something like courage. Even the Europeans who are born in India are deprived of the sense of courage and special skills which their ancestors had. The examples of courage exhibited by them in some cases are thanks to the imagination granted to them by nature (Montesquieu 2014, 14/III). In the following claims of Montesquieu, he went on humiliating Indian, in general sense the Eastern communities, and defined them as 'barbarous' people. His harsh criticism of the Eastern communities via Indians is a bit extravagant and far from the sense of fairness; since the East is not just made up of India. In addition, taking the community that is under investigation just from negatives examples is not a suitable approach in scientific sense.

Due to the fact that hot climate makes people's actions difficult, laziness and immobility is perceived as a source of happiness in the East. This defect granted to human by climate could be strengthened by the law maker with wrong laws. As an example, the laws by the Indian Ruler Foe are regarded in this sense (Montesquieu 2014, 14/IV). These laws that support immobility made the people lazier by keeping them away from the sense of property. Indians, already lazy people, became lazier when they left the idea of owning a property (14/VI, 251). Therefore, India is full of monks having a morality of living without working (14/VII, 251). According to Montesquieu, Chinese rules produced very successful laws and tried to lessen the negative effect of climate (14/V, 250). The task given by Montesquieu to the law makers is to make laws considering the effects of climate on people, since laws increase or decrease the effect of climate.

Montesquieu made a connection between human's life and the structure of laws with the geographical conditions other than climate. As an example, a mountainous country or a country with low lands, an island country or a country surrounded by rivers affect the defence of a country directly. Therefore, there always existed great empires in Asia, since Asian communities did not have natural barriers to be used in defending themselves. For that reason, the powerful em- pires were able to invade weaker communities very easily. In Europe, it was not easy to have powerful empires that could invade each other since there some natural parts and barriers (Montesquieu 2014, 17/VI). In fact, according to Montesquieu, being able to invade a place easily made Asians have a spirit of a slave. To him, no country with a strong feeling of freedom did not emerge in Asian continent (17/VI, 296). It is thought that such views of Montesquieu were formed with a strong prejudice. It is not possible to agree on these comments with have a scientific or historic link.

Apart from that, Montesquieu made a connection between alcohol consumption and the laws related to it and coldness and hotness of climate. According to him, since human body loses more water in hot countries, the most available drink is water. Strong drinks in these climates harm people in hot countries. Therefore, the ban on alcohol by Prophet Mohammed for Arabs living in a hot climate is a suitable law for the structure of the community. Similarly, the ban on wine by the Carthaginians living in a hot region was a law suitable for the climate. The climates of these two countries are almost the same. However, according to him, there is no need for laws banning on alcohol in cold northern countries, since alcohol is not so dangerous for the body there (Montesquieu 2014, 14/X). In this comment of him, Montesquieu looks as if he put the effect of climate in front of the effect of religion in making laws. However, banning on alcohol by Prophet Mohammed is because of different reasons rather than climate. If the opposite were true, taking alcohol would be free for people living in cold countries while it would be banned in Arab countries. Therefore, this claim of Montesquieu is a forcing explanation having no connection with religious and social realities.

\section{OBSERVATIONS AND DISCUSSION}

In holy texts, there is a relation between the ways of believing in religion and the locations where people live and living conditions. In Qur'an, there are some verses about the fact that Bedouins living in the desert have a tendency to deny religious facts: "The Bedouins are stronger in disbelief and hypocrisy and more likely not to know the limits of what [laws] Allah has revealed to His Messenger. And Allah is Knowing and Wise.” (Qur'an 9: 97). In the interpreta- 
tion of this verse, some thinkers expressed that the characteristics of Bedouins are not easy to discipline due to their nomadic life styles, therefore, Islamic life style which has limits determined with strict rules is difficult for them to practice. What's more, depending on this interpretation, there is some having a claim that Qur'an encourages a settled life instead of a nomadic desert life (Bulaç 2013, Footnote 15). An attempt to relate belief with the place is also given Bible. Therefore, God placed people in different geographies of the world on purpose in order that they know each other and seek for Him (Bible Prophets 2013, 17: 25-27).

Ibn Khaldun accepts that there are some necessary, casual connections in the nature. However, these necessary connections for him were placed in the nature because of the preference of God and cannot limit the infinite power of God. As an example it is normal that people accept that there is a necessary connection between with the termination of night and the sun rise since the sun rises every day; because the phenomenal knowledge witnessed in this issue has never changed. According to Ibn Khaldun, the reason for this case is the preference by God to carry out the things depending on the order and system human being is accustomed to. It is called adetullah or sunnatullah. However, having a law and necessity do not mean that God subjects to this. In other words, if God wishes, He cannot permit the sunrise tomorrow.

This case is different from the perspective of Montesquieu. According to him, it necessary for God to follow certain laws while creating and managing the universe. For him, God made the laws and rules he will depend himself. He himself determined what these rules must be like thanks to his wisdom and power. But, according to Montesquieu, it is not logical to say the universe could be managed without a series of rules, since it is not possible for such a big and complex universe to exist without rules and laws. Therefore, Montesquieu says that the rules God would follow were created by God himself and he neither refused the existence of God nor did he leave the idea of having a law which is dominant over everything.

Depending on the observations of Montesquieu within the social context, his acceptance of the relation he made about the fact that the climate, the place inhabited and natural conditions affect the characters and behaviours of people is a very strict and extremist attitude for us. Even though the suppositions that there is a connection between climate and human behaviours were adopted by many people, it is a very demanding analysis to explain it with a determinist idea of having a law. Despite the fact that it is not as extreme and strict as the same supposition, the acceptance with regard to the casual relation between the climate and human behaviours is valid for Ibn Khaldun as well. But Ibn Khaldun does not accept this case as a basic situation playing a determinant role in the making up of laws.

Both thinkers accept that climate and weather temperature have a strong effect on human being, however they do not agree on the issue that the direction of this effect and what kind of weather temperature have positive or negative effects. Ibn Khaldun expressed that climates have an effect on human being and warm central climates are more suitable for human life and people living in these regions are generally consistent and proper in their behaviours. Due to the fact that Spain, Northern Africa, Anatolia, India and China are considered in the central climatic zone in the classification of Ibn Khaldun, the communities in these countries are developed in all respects, far from extremism, healthy physically and mentally, improved in science and art and in short they established superior civilizations.

On the other hand, warm climate is not a desired thing for Montesquieu, since people living in these climatic zones are indecisive and incompatible. Climate does not have an effect on these people so as to make them guide to a direction. In addition, the people of Spain, Northern Africa, and Ottoman, a part of China and India who were praised by Ibn Khaldun and shown as the examples of high civilizations are regarded as underdeveloped by Montesquieu. They are lazy, far from cleanness and they are the communities without a high civilization and well-organized laws. Investigating the same communities in terms of the effect of climate and reaching so different results is a serious difference that should be taken into consideration for both thinkers.

The praise by Montesquieu for the characters of the people living in cold climates and his expression that cold weather has positive effects on human behaviours compared to hot weather gives an impression of a subjective expression depending on the fact that he is a European. He 
only talks about the southern parts of Italy and Spain when he mentioned about the southern climate which he defined the people there as low morality, lazy and coward. He has no explanation for France and England where he lived such that. In addition, he has intensive criticisms for the Eastern and Asian countries and it is more than a criticism and is actually an insult.

Not that Montesquieu was aware of these extremist criticisms, he said in the introduction of the book "the Spirit of Laws" that he prepared the book as a result of twenty-year research and effort and it must not be criticized with a reading of a few hours. However, scientific mistakes in the book and expression that do not go well with social structure or sociological realities make a criticism for the book inevitable. What's more, he was criticised not only by us but also Voltaire, his contemporary and friend, in a very harsh way. According to Voltaire, Montesquieu applied for arranged sources in the book the Spirit of Laws, uttered so many incorrect judgements, he gave other's expressions as if they were his own ideas.

Some people criticized Ibn Khaldun thinking that he exaggerated the effect of climate on human being. In fact, there were some more criticisms the views of Ibn Khaldun over the effect of climate on human being were not original and it had been expressed in the Islamic geography for a long time. It is true that Ibn Khaldun had some exaggerations in some situations over the effect of climate on human life. In particular, his division of the world into seven climatic zones and the issues with regard to these climatic zones do not base upon objective features. However, they are more successful, scientific, compatible with realities and more reasonable compared to the climatic theory of Montesquieu.

Even though the results they obtained in terms of climatic theories, the two thinkers had similarities in terms of the sources and methods they applied while forming their theories. Ibn Khaldun was born in Tunisia, travelled to Andalusia due to his familial connections, went to a great many places in Africa and lived in Egypt. Montesquieu was born in France and travelled to a great many countries such as England, Spain, Italy and Holland. Both were interested in politics and both were judges. Therefore, it is not wrong to say these personal features of theirs had an impact on their theories. In particular, the knowledge they had in their travels comprised the starting point of their phenomenal observations. For that reason, the basic component both thinkers depended was their personal observations.

Also, both thinkers were in an effort to build scientific bases for their theories they formed depending on their observations. In this context, Ibn Khaldun maintained that hot weather brought about the expansion and extension of vapour and opened the pores on the skin, so it caused a relaxation and lightness in human. Similarly, Montesquieu claimed that the length and flexibility of the fibres and muscles are determined according to the temperature of the weather and it had an impact on the heart and other features of human being. However, it is true that both thinkers did not apply for valid scientific sources for their period and that they achieved these results depending on their personal observations which they thought scientific. Today, it is accepted that thinkers use these claims which are far from scientific validity in order to support their theories.

It is likely to say that Ibn Khaldun takes the effect of climate on human from a broader perspective. According to him, individuals shaped in terms of the effects of climate could shape the places they live in this respect and a lot of components like building, eating and drinking, economic and political relations which are related to the civilization of social life come out in this process of this effect. Montesquieu examined the effect of climate in a narrower sense. The issue he particularly deals with is how and in what way the effect of climate appears in making of laws.

\section{CONCLUSION}

The views of Ibn Khaldun and Montesquie over climate were mentioned in a great many studies. However, the views of the two thinkers over climate were given comparatively in the current study for the first time. What's more, this comparison was made in the context of how climate changes the characteristics of people and the lives of communities in general sense.

I hope the current study that was carried out comparatively to investigate the effects of climate, geographical and natural conditions on human being and on different status of him that was put forward by the two different thinkers living in two different cultures, two different regions and two different times would be beneficial for the readers. 


\section{NOTE}

Earlier version of this paper presented at $1^{\text {st }}$ International Ibn Khaldun Symposium, Çorum, Turkey (01 03 November, 2013)

\section{REFERENCES}

Bulaç A 2013 Kur'ân’ý Kerim Meali. Istanbul: Birim Publishing.

Gürkan Ü 1988. Montesquieu ve Kanunlarýn Ruhu. Ankara University, Journal of Hukuk

Fakültesi, V: 40, I: 1, pp. 9-31. From <http://auhf. ankara.edu.tr/dergiler/auhfd-arsiv/AUHF. 1988-4001-04/AUHF-1988-40-01-04-Gurkan.pdf $>($ Retrieved on 22 June 2013).

Ibn Khaldun 2012. The Muqaddimah. Translator: Franz Rosenthal. From <http://asadullahali. files.wordpress. com/2012/10/ibn_khaldun-al_muqaddimah.pdf > (Retrieved on 18 September 2013).

Kutsal Kitap Dernegi (2013). Incil Meali (Bible Translation). From <http://kutsalkitap.org> (Retrieved on 15 September 2013).

Long RT 1996. Aristotle's Conception of Freedom. The Review of Metaphysics (49), p: 775 - 802. From
$<$ http://praxeology.net/AriConcFree.pdf $>$ (Retrieved on 15 September 2013).

Macfarlane A 2013. Montesquieu and the Making of the Modern World. Create Space Independent Publishing Platform. From <http://www.alanmacfarlane. com/ TEXTS/Montesquieu_final.pdf $>$ (Retrieved on 16 September 2013).

Montesquieu 2014. The Spirit of Laws (Original Published in 1748). Translator: Thomas Nugent. Kitchener, Ontario, Canada: Batoche Books. From <http:/ /socserv.mcmaster.ca/econ/ugcm/3ll3/montesquieu/ spiritoflaws.pdf> (Retrieved on 03 May 2014).

Montesquieu 2008. Persian Letters (Original Published in 1721). Translator: Margaret Mauldon. Introduction: Andrew Kahn. New York, USA: Oxford University Press. From<http://m.friendfeed-media.com/ b4431911cb8c033f6fe71da63d53a56e8920f11d> (Retrieved on 17 September 2013).

Religious Affairs Administration of Turkey (2013). Kur’ân’i Kerim Meali. From <http://kuran.diyanet. gov.tr/> (Retrieved on 15 September 2013).

Uludag S 2009. Girip (Mukaddime içinde). Istanbul: Dergâh Publishing.

Voltaire 1947. Feylosofça Konusmalar ve Fikralar. Ankara: MEB Publishing. 